Hybridity and Colonial Desire in Ahdaf Soueif's In the Eye of the Sun

\title{
Ahdaf Soueif'in In the Eye of the Sun Adlı Yapitında Melezlik ve Sömürgeci Arzu
}

\author{
Ayşe Çurçır* \\ Erzurum Technical University, Faculty of Letters, Department of English Language and Literature, \\ Erzurum, Turkey
}

\begin{abstract}
Ahdaf Soueif is a contemporary Egyptian-British novelist and cultural theorist and In the Eye of the Sun, her first novel published in 1992, tells the emotional, sexual and academic journey of Asya, an Arab Muslim student, and later professor, of English Literature in England and Egypt. In this novel, Soueif emphasises post-colonial reconsiderations and accordingly demonstrates her conscious attempt with extensive references to the colonial and imperial history of Egypt. The present study in particular looks at desire and hybridity in the novel with Robert J. C. Young's Colonial Desire: Hybridity in Theory, Culture and Race and offers an interpretation of the post-colonial Other's interpellation by the culture of the coloniser and of desire which is problematized by reading about desire in imperial culture. In investigating these points, it is stated that the problematic and hegemonic centrality of English Literature for the Arab female characters makes post-colonial texts haunted and postcolonial discussions around adultery, alterity and sexual imperialism shape the content of the novel. By describing and considering these issues, this study attempts to offer a post-colonial reading of the novel.
\end{abstract}

Keywords: Ahdaf Soueif, Robert Young, Post-Colonial Theory, Colonial Desire, Hybridity, Alterity, Sexual Imperialism, Interpellation.
Öz

Çağdaş Mısırlı-İngiliz roman yazarı ve kültür kuramcısı Ahdaf Soueif, 1992 yilında basılan ilk romanı In the Eye of the Sun'da Müslüman Arap bir İngiliz Edebiyatı öğrencisi, ardından profesörü olan Asya'nın, Mısır ve İngiltere'deki duygusal, cinsel ve akademik yolculuğunu anlatır. Bu romanda Soueif, sömürgecilik sonrası yeniden incelemelerine değinir ve bu bilinçli çabasını Mısır'ın imparatorluk ve sömürge tarihine verdiği birçok atıfla gösterir. Bu çalışma, özellikle arzu ve melezlik kavramlarını Robert J. C. Young'n Colonial Desire: Hybridity in Theory, Culture and Race adlı yapıtı üzerinden inceler ve sömürgecilik sonrası Öteki'nin sömürgecinin kültürüne çağırılmasını ve sömürgecinin kültüründe arzu üzerine okumalar yapıldığı için sorunsallaşan arzuyu inceleyecektir. Bu noktalara değinirken, İngiliz Edebiyatı'nın Arap kadın karakterler üzerindeki sorunlu ve baskın merkeziyetinin sömürgecilik sonras metinleri lanetli yaptığı ve eşini aldatma, ötekilik ve cinsel yayılımcılık kavramlarının romanın içeriğini şekillendirdiği vurgulanır. Çalışma, bu konuları inceler ve açıklarken romanı sömürge sonrası söylem ışığında okur.

Anahtar Kelimeler: Ahdaf Soueif, Robert Young, Sömürgecilik Sonrası Eleştirel Söylem, Sömürgeci Arzu, Melezlik, Ötekilik, Cinsel Yayılımcılık, Çağırma. 


\section{Ahdaf Soueif's Anglo-Arab Writing}

Ahdaf Soueif's fiction shows that no one can describe with certainty who s/he is, as Edward Said (1994) says, "No one today is purely one thing" (p. 407), because imperialism consolidated the mixture of cultures and identities, and its paradoxical gift is to make people believe in deceptive purities and assume that they are one thing. Soueif's fiction is an intersection of different concerns and writing practices, and she connects with Muslim female novelists writing in English around the globe and with Arab feminists and novelists writing mainly in Arabic. Her fictional writing is also connected to European canonical literature, especially the novels featuring female protagonists, such as Middlemarch, Anna Karenina, Wuthering Heights and Madame Bovary (Malak, 2005, p. 127). Anastasia Valassopoulos (2008) emphasises that Soueif writes fiction that offers a blend of sociology, history and political science and "weaves elements that are directly of interest to post-colonial critics" (pp. 30-31). As these intersections exemplify, the concern of this paper is to address different forms of hybridity in Soueif's fiction and to point to the problematic and hegemonic centrality of English Literature for the post-colonial subject that will extend into discussions of alterity, adultery, ambivalence and colonial desire.

In her fiction, Soueif discusses racial and cultural hybridity and emphasises hybridisation as a fundamental part of the identity and culture of both the coloniser and the colonial/post-colonial subject. Cultural hybridity is celebrated in her writings; however, it is not a happy hybridity that is underlined, but an understanding that all cultures are inherently and inescapably hybrid. As Edward Said (1994) states in Culture and Imperialism, "Partly because of empire, all cultures are involved in one another; none is single and pure, all are hybrid, heterogeneous, extraordinarily differentiated and unmonolithic" (p. xxix). The questions around hybridity are multi-layered in Soueif's writings; for example, she posits mezzaterra as a form of hybridity, a spatial mixedness, but not fusion, that she glamorises with the romantic and heterogeneous Cairo of her childhood and the heterotopic Tahrir of the 2011 Revolution. In her fictional writings, on the other hand, hybridity is consolidated as a theme and expressed either peacefully as the condition of bilingual/bicultural upbringing and violently as the result of colonialism. Similarly, while discussing the effects of Western education, Geoffrey Nash (2009) states that education creates isolation and exile on the colonised/post-colonial subject (p. 357) and In the Eye of the Sun intensely discusses hybridity, ambivalence and alterity through a questioning of education in the imperial centre and of the interpellation by the culture of Empire. With these in mind, this paper suggests ways of understanding how cultural, racial and linguistic hybridity are contested in the novel alongside colonial desire and it is useful to provide basic definitions for some post-colonial concepts.

Ambivalence is transferred from psychoanalysis and adapted by Homi Bhabha into colonial discourse theory. Bhabha argues that a pattern of repulsion and attraction characterises the relationship between the coloniser and the colonised who is not simply opposed to the coloniser because colonial discourse may be both nurturing and exploitative. Bhabha's understanding of ambivalence unsettles the binary relationship between the coloniser and the colonised (Young, 2005, p. 153). Bhabha (2003) develops this connection further with mimicry and mockery and indicates that ambivalence disturbs the authority of the colonial discourse (pp. 8889). It should be noted, however that, Bhabha's understanding of ambivalence is controversial, for it suggests that colonial discourse carries seeds of its destruction, which in turn problematizes the struggle for liberation. On the other hand, colonial discourse is ambivalent because, as Bhabha argues, it does not want the colonised subject to be the exact replica of the coloniser because it would be threatening for the coloniser. Bhabha's main contention is that the subjectivities of both the coloniser and the colonised are constructed by the ambivalent colonial discourse, and this ambivalence decentres the power of the authority, thus making it connected to the concept of hybridity (Ashcroft, 2001, p. 187; Ashcroft, Griffits \& Tiffin, 2004, p. 102). Robert Young (2005) indicates that Bhabha is concerned with "constitutive ambivalence" that is at the heart of colonial discourse: "an ambivalence that its appearance in a non-European context only accentuated" (p. 153).

Colonial discourse encourages the colonised subject to mimic the coloniser and accept his standards, values, assumptions, opinions, morals and habits. The result, Bhabha (1984) argues, is a blurred copy, or mimicry, 
that can be threatening for the coloniser (p. 127). Mimicry is not far from mockery, and Bhabha (1984) indicates that it points to a crack in the certainty of the colonial discourse; it is "the desire for a reformed, recognizable Other; as a subject of a difference that is almost the same, but not quite" (p. 126). Post-colonial cultural and artistic works emerge from this uncertainty in the colonial power (Ashcroft, 2001, pp. 3, 52, 142; Young, 2005, p. 153) because "mimicry repeats other than re-presents" (Bhabha, 1984, p. 127). Aijaz Ahmad (2000) describes African and Asian literatures as "mimicries" (p. 216) and colonial mimicry is indisputably related to power because it is the mimicry of the original and the true that exists at the source of power (Ashcroft et al., 2004, pp. 88, 101). As Benita Parry (2004) suggests, hybridity, mimicry and ambivalence have transformed Post-Colonialism from a critical anti-colonialism to a more reconciliatory mode of criticism (p. 4); in other words, from a materialist to a textual critique.

The crucial thing for Bhabha is that Post-Colonialism, Postmodernism and Post-Feminism represent liminal spaces because of the appellation post (Ashcroft, 2001, pp. 145-146; Bassnett \& Trivadi, 2002, pp. 5-6) and liminality is central in understanding ambivalence (Said, 1994, p. 170). It denotes an in-between space where cultures meet and cultural change occurs, which is the transcultural Third Space. The colonised subject lives in the liminal space that is between colonial discourse and the assumptions about a non-colonial identity, and liminality creates a process of engagement, contestation and appropriation. For Bhabha (2003), liminality is central to hybridity, and he describes this symbolic liminal space of interaction as a stairwell in which there are no polarising assumptions, hierarchy and binaries (pp. 3-4). This demonstrates a very complex interaction; however, an identification with liminality does not suggest a movement between identities for Bhabha.

\section{Ahdaf Soueif's Hybrid Fiction}

Amin Malak (2005) describes Soueif's fiction as a hybrid of numerous forms, East and West, urban and rural, and classical and modern (p. 127) that reveals an inescapable post-coloniality. In her semi-autobiographical bildungsroman In the Eye of the Sun, Soueif explores many polemical issues she often discusses in her writings such as nationalism, identitarian Islam, gender politics and female sexuality. The book is a dense epic-length novel that expands into eight hundred pages depicting the emotional, sexual and intellectual journey of Asya in Egypt and England. Asya is portrayed as a contemporary hybrid; an Arabic speaking woman who speaks English as though "she'd 'just come from Oxford"" (Soueif, 1999, p. 97). She identifies with Victorian female novel characters and is a Muslim woman in the slowly secularising Egypt to which her name attests. As explained in "Mandy" in Sandpiper, Asya means Asia in Arabic (Soueif, 1995, p. 93) and Asya is an Arab/Egyptian woman though she has doubts that Egyptians might be African. As Malak (2005) notes, Asya is the name of the pharaoh's barren wife in Islam who finds baby Moses adrift on the Nile, and saves and adopts him, and it unites the pharaonic history of Egypt with its Islamic heritage (p. 130). Nonetheless, Asya is never called by her name; she is either a pussycat, babe, man, princess, or sweetie (Cariello, 2009, p. 319), and she cannot pronounce her name in a language class which perpetuates a problematic hybridity for her.

In the Eye of the Sun is a heavily political novel and it draws attention to post-colonial issues such as the centrality of language, the legacies of Empire in contemporary politics, economy and institutional education in the post-colonial states, forced migration, exile, miscegenation and civilisation. It is a novel about decolonisation, and it generates a reading of a post-independence society. Its central concern is the ambivalent relationship of the post-colonial subject with the culture of the coloniser, and it looks at literature, especially the novel genre, as an institution of the Empire and problematizes the act of reading for the post-colonial female subject. In The Map of Love, a later publication, the act of reading is reconciliatory and reconstructive, but in In the Eye of the Sun, reading creates ambivalence, alterity and a problematic hybridity. Reading mobilises the post-colonial subject in The Map of Love, but in In the Eye of the Sun, it paralyses Asya and makes beginnings and endings problematic for her. Although the novel follows the trajectory of a linear storyline with its bildungsroman structure, there is a deferral of ending, and Soueif does not create a familiar return story. 
Within the larger pattern of Asya's life in Egypt and England, In the Eye of the Sun chronicles the history of Egypt between the years 1967 and 1980, and the history of the country intersects with the personal history of Asya and her family. The novel starts with the catastrophic and humiliating defeat of the Egyptian Army in the Six-Day War in 1967 and gives historical depth to the repressive political climate for the following two decades. Although the novel is intensely historical, its political content is somehow situated outside Asya's life, and to support this, it appears as intrusions in the form of newspaper reports that intersect and interfuse with the narrative only to create a stage for the action to take place. Valassapoulos (2008) indicates that "political contexts disappear in the face of internal psychological struggles" (p. 124) in the novel. Soueif (1999) describes In the Eye of the Sun as a classical novel of education and says, "history and politics come into it only insofar as they affect our protagonist and those around her" (Massad and Soueif, p. 83).

Beginning is a problem for Asya because she is a post-colonial subject, and In the Eye of the Sun (1999) starts in media res with a letter that Asya writes in London to Chrissie in Cairo, "it's only been five years [...] it isn't long at all in the history of a country" (p. 3). Nada Ayad (2016) indicates that the opening of the novel "articulates one of the projects of the novel: to chronicle the effects of [the] shifts on the daily lives of ordinary Egyptians" (p. 57). History, or time, is established as a dilemma, and the opening invites the reader to think that the long history of Egypt will shape the worldliness of Asya who will carry it as a burden. However, the novel shows that some carry it as a scar of a humiliating wound and painfully remember/wear it. Likewise, Asya's witness is her body (Cariello, 2009, p. 337). The ending reasserts the same struggle, and, following a Qur'ānic ${ }^{i}$ recitation, the novel turns to the anguished inner speech of Asya, "To see the end in the beginning. But in life you can only see the end when you come to it" (Soueif, 1999, p. 765). The end is in the beginning, because this is a novel, and it is possible, and Asya is often reminded that life is not a novel. For many interesting reasons, In the Eye of the Sun begins with its ending in 1979 -the pastness of the past being its central problem- and ends with a questioning of beginnings. It is a mobile novel of histories, hybridities, departures and arrivals, and returns are traumatic in it. They are ambivalent and inseparable from memories and make the novel a questioning, within the syncretic post-colonial realities, of the returning itself. Asya's beginning is very novelistic in an imperial sense, and this hinders her attempts of liberation. On the other hand, liberation is not the necessary telos in her story (Massad and Soueif, 1999, p. 75; Valassapoulos, 2008, pp. 125-126; Maleh, 2009, p. 16).

Asya mistakes the words on the pages of English novels that she reads for the realities in Egypt and England, and beginnings and returns become powerful metaphors for colonialism in Soueif's fiction. The presence of the unending colonial past in the present creates the ambivalence that this novel portrays, and its tension is authenticity. The novel is haunted by English canonical novels, and it haunts/writes back. Marilyn Booth (1994) states that it is also "a postmodern rewrite of two landmark midcentury works of Egyptian fiction" (p. 204): Naguib Mahfouz's Cairo Trilogy and Latifa al-Zayyat's The Open Door. This Arab/post-colonial double of Middlemarch makes Asya a suffering textual child of the Empire whose fundamental problem is to live a real life without the imposition of others -and of literature, which is underlined at certain moments with casual references to Don Quixote. Malak (2005) argues that the "dislocation between the realm of Western literature and the reality of the Middle Eastern world constitutes a leitmotif feature that runs throughout Soueif's fiction" (p. 134).

In this novel, Soueif comments on hybridity as one of the violent and inescapable results of colonialism. Asya's beginning is determined by her mother, and colonial history, like her mother's is. In the course of the novel, she is sent to England for graduate study and returns as a professor of English to Cairo University like her mother. The only difference is that her mother has her and her sister Deena while she is writing her dissertation in England and Asya's lot is a miscarriage and adultery. As an upper middle-class Arab Muslim woman, she is married to Saif, but the marriage is unconsummated and troubling. Boccardi (2009) indicates that consummation "is the means to imprinting the romance onto reality" (p. 111) and Asya is obsessively concerned with her sexuality and intellectual identity throughout the novel seeing romance and sex as the 
opposites of a binary. Her hybridity is also problematized by desire and reading about desire in the imperial culture, especially in novels, which does not bring resolution to the narrative because it heightens the ambivalence the post-colonial subject feels.

The novel follows the serene trajectory of a bildungsroman, paradoxically becoming a war narrative at times, and describes the turmoil of the 1967 Six-Day War when the teenager Asya studies for the Thanawiyya 'Ama, the General Certificate of Secondary Education. There are the official celebrations of the 1952 Revolution for its fifteenth anniversary and army trucks run over Asya's uncle, Hamid. Like the car-park attendant Mansur in The Map of Love who carries the burden of history on his dead body after a terrorist attack, Hamid carries history as a scar. He loses one arm, and his brain is also affected symbolically in the area of memory. As a parallel to this, the novel begins in 1979 at a hospital in London when Hamid undergoes an operation for what the Army of Egypt did to him in 1967: "a self-injurious army that damages the same people it is supposed to defend" (Malak, 2005, p. 131). However, for Asya, everything is entertainment and a break from study.

Asya memorises the Socialist Laws of July; she is a child of the 1952 Revolution, and she should study history for the exam. However, she secretly reads Robinson Crusoe taken from her mother's collection: "even Robinson Crusoe is preferable; it seems, to the details of Sykes/Picot agreement" (Soueif, 1999, p. 45). The history of the Arab Near East is disturbingly there, and the dilemma is established with the actual practice of novel reading. Asya lives in the Arab East that the Sykes/Picot divided and is reading Robinson Crusoe in the midst of the Six-Day War, a novel that is considered to be the first novel of English Literature, a novel about the institution of the novel genre (Eagleton, 2005, pp. 22-23), and imperialism and colonialism. All that she wants, however, is to read drama and novels forever and ever, and maybe an end to the war.

War, however, is a material reality and Asya's mother Lateefa says, “This isn't a game, this isn't theatre. This is a war" (Soueif, 1999, p. 55). Dada Zeina, the family servant/nurse, has to wait in the queues for sugar, tea, oil and flour, and the reader hears patriotic war songs and the words of General Nasser popping abruptly from the pages. Asya cannot watch Peyton Place anymore because television shows only footages of past military parades. After all, the Egyptian army has to withdraw in the eye of the sun; Thanawiyya is postponed, and they lose the War. For Asya, novels are not good anymore and she, for the first time, realises that history is taking shape. It is such a war that there is not any family in Egypt that does not lose a son or a brother that summer. To his luck, Ismail Mursi, Asya's grandfather, the self-exiled Palestinian, does not lose a child, but his son loses his memory.

After setting the historical stage, the novel starts exploring the effects of reading the literature of the coloniser. As suggested in its opening, Asya repeatedly questions her preferences throughout the novel and feels that her life is imposed on her because her academic parents always want her to teach at the academy. In the opening, Asya desperately wants to study literature and writes on her university application form 'Cairo University, Department of English' for sixteen times and invalidates it. However, she never feels self-sufficient as a professor of English, and although she sees culture as key to transformation, she is doubtful. Asya embraces English Literature and wants to join the department. She secretly loves her professor of Poetry, a controversial figure because of the British accent of his English and described as the "first Egyptian head of an Egyptian Department of English" (Soueif, 1999, p. 92). After the issuance of the National Charter in 1962, professors are invited to participate in society to instil a socialist mentality in the universities in Egypt (Crabbs, 1975, p. 387) and, for the poetry professor, "Art is at the service of the Revolution. Will there be no end to British imperialism?" (Soueif, 1999, pp. 94-95). Asya organises poetry and music nights and meets Saif on the steps of the library of the Department of English though he insistently lies to his friends that they met at an antigovernment demonstration. Asya's beginning is the beginning of a new phase in the history of Egypt and the ambivalence is visible because her story starts at the English Literature Department in Cairo University when the country is battling war after war and struggling to recover from the legacies of Empire. 
Asya is an interesting hybrid, a character of paradoxes, and is often depicted as superficial. Saif says that she likes Joan Baez, Bob Dylan, Sayyid Darwish, Simon and Garfunkel and the old songs of Abd el-Wahab at the same time. She enjoys the privileges of an upper-middle class life in Zamalek, goes to operas, ${ }^{\text {ii }}$ but also espouses Western Marxism. Asya criticises the repressive politics in Egypt, but admires Nasser (Ayad, 2016, p. 58). Booth (1994) indicates that "privileges shackle those who enjoy it" (p. 204) and this tension is emphasised in the novel when people question Asya's irritating impartiality and theoretical stance on polemical issues. While discussing polygamy with a group of international friends in England, Asya says, "I don't believe in polygamy [...] "but I don't condemn it out of hand" (Soueif, 1999, p. 401), but a girl from the group asks her to choose a side. Malak (2005) defines Asya's stance as "inherently polyglot": "her hybridized discourse rejects the principle of monologue and composes itself by selecting from competing discourses" (p. 131). It should be stated also that, like Asya, Soueif defends impartiality in an interview and says, "we have no option but to NOT choose sides" (Mahjoub, 2010, p. 59).

Asya often questions received ideas, or "received value systems" (Booth, 1994, p. 205), that shape her tastes and identity. She cannot decide from where her understanding of vulgar comes, perhaps from her father and Saif and she fears that she is "little more than an object in the male consciousness" (Nash, 2008, p. 29) as Faten in the "The Water Heater" in Sandpiper. Parenthetically to note, Faten is beaten by her brother because she studies French that symbolises the language of the coloniser (or the Male Symbolic) for the incestuouslydesiring brother. The voice of Saif is always in Asya's mind as a chorus dictating to her what to think and his control of language gives structure to the novel. Saif narrates certain passages which create a sense of doubling and some scenes are narrated firstly by Saif and then by Asya. In imperial terms, the structure of the novel can be described as the construction of opposites and, because Saif frequently lies throughout the novel, the reader questions his authenticity.

When Saif and Asya meet at the library steps, Saif tells Asya that she is Asya, and he will never call her by her name after that. Asya narrates the same scene and the voice of Said circumscribes her sentences and subverts the normal rules of narrative: "he was proud of his perfect feet and his smooth, muscled, brown back. "So what the hell did you feel when you touched the bastard"' (Soueif, 1999, p. 99). Boccardi (2004) describes their encounter as "epidermic" (p. 316) and it is seen that the multiplicity of perspectives decentres the consciousness in the novel when the reader learns in the opening that Asya will betray Saif. Booth (1994) emphasises that the first-person musings of Saif "cut across our intimate knowledge of Asya" (p. 204). As a correlative way of interpreting, Asya's narrative stands as a testimony and after-narrative because it is clear that she knows Saif as if they met long ago.

To return to the prior point, Asya speaks of theoretical sadness and cannot confront divorce because Saif does not tell her categorically that it is over between them. She draws flowcharts about her emotions and rejects when Saif wants her to describe her betrayal in a flowchart. She theoretically and coldly defines the components of life: "Love: a quarterly visit to a husband who treats her like a pet; to be indulged and given treats as long as she behaves - a husband who turns his back on her every night" (Soueif, 1999, p. 353). She criticises Saif because he likes naming feelings. She likes exams because they are defined and finite and when she writes her dissertation, only one category does not trouble her: time. The novel's conclusion reasserts her contradictions and does not solve them because ambivalence is at the centre of the novel, and hybridity and alterity keep this centre at the centre.

Asya is a post-colonial hybrid, and her self-discovery is filled with self-doubt, self-contradiction and sometimes self-destruction. D'Alessandro (2011) emphasises that Soueif's female characters cannot manage to see themselves as "integrated subjects" (p. 44). The difficulty lies in the fact that she inherits ambivalence from her mother, who loved her English teacher Miss Sage, and in whom she saw "a whole freer way of life and thought" (Soueif, 1999, pp. 458-459). Asya's ambivalence is based on another and reproduced ambivalence, and Soueif points to the repetitious displacement of the post-colonial subject because past is not 
past. The violent contradictions in the life of the post-colonial subject create fragmentations of identity and estrangement, and the culture of the West becomes a signifier of positivity which is inherently problematic for the post-colonial subject. Booth (1994) similarly emphasises that there is an undercurrent in the novel, an ambivalence and a self-questioning of the postcolonial intellectual vis-à-vis Western societies (p. 205).

Soueif relates this problem mostly to the acts of reading and indicates that Lateefa never told her mother that she read novels. In the 1930s Cairo, Lateefa, an Arab Muslim girl wants to be like the British girls driving army trucks in the streets of Egypt and, forty years later, Asya is hopelessly thinking about Empire in the Embankment in London. Unhappy, alone, disillusioned and unsettled by the lure of fixity and roots, she looks at the Thames, which she sees as important and mighty as the Nile, and the two rivers interlace in her memories of Empire. They become the collective memories of the Egyptians and other colonised nations:

Built of course on Egyptian cotton and debt, on the wealth of India, on the sugar of the West Indies, on the centuries of adventure and exploitation ending in the division of the Arab world and the creation of the state of Israel(Soueif, 1999, pp. 511-512).

The reader never hears the story of Miss Sage or what happens to her after the 1952 Revolution when her mother and another professor triumphantly seize the English Department from the British. We only know Lateefa's story who loved English literature from that day on. Asya follows her mother's example, but she constantly meditates on the use of a Ph.D. in English, or teaching metaphors and linguistics to the students in Cairo. It is important to note that, as Booth (1994) emphasises, Asya's dissertation "with appropriate irony" (p. 205) is on metaphors. After all, Asya does not understand why English Literature should matter to Egyptians. Knowingly ironic and subversive, this is a deliberate attempt in the novel to understand the effect of an attachment to the culture of the Empire that distorts realities, challenges belongings and limits the life of the post-colonial subject. Asya weeps like a child for the past and articulates her fears eloquently:

they wouldn't have to look in the dictionary every two minutes, at least they would recognise for themselves the references to the Qur'an or to Imru' al-Qais, at least they'll know that when a character refers to 1882 he's talking about 'Orabi and the occupation and when he refers to 1919 he's talking about Sa'd Zaghloul's revolution - they will know how the words sound, for heaven's sake. What is English Literature to them or they to English literature that everyone must live in torment over it (Soueif, 1999, p. 452).

Remembrance is a feminist issue (Heilmann \& Llewellyn, 2004, p. 142), and Asya here thinks about women: Miss Sage, her mother, herself and a barren Madame Zeinab who loses her husband in the middle of her Ph.D. in England and returns to Egypt with his dead body. Zeinab never completes her studies, stays as an instructor and Asya fears that she will end up like her. Out of fear, Asya thinks that she should not have studied English Literature, but she is in England and "the damage was already done" (Soueif, 1999, p. 459). She, however, is conscious of her alterity and thinks that a sinister insidious colonialism is implanted in her soul; a colonialism that no rebellion can diminish, or no treaty can put an end to. If she is in England, the British Empire is responsible for this, but she has not come empty handed. Egypt, as the other setting, becomes a referent and measure by which the Empire is evaluated (Massad and Soueif, 1999, p. 76) and Asya's remarkable description of the imperial encounter becomes the central scene of the novel because, as she too states, Empire bears the traces of the Other.

I bring you poetry as great as yours but in another tongue, I bring you black eyes and golden skin and curly hair, I bring you Islam and Luxor and Alexandria and lutes and tambourines and date palms and silk rugs and sun-shine and incense and voluptuous ways (Soueif, 1999, p. 512).

As the post-colonial Other, Asya feels displaced in real life and often thinks on the nature of literature and its power to move the self beyond reality. She is ignorant, however, of her post-colonial alterity because her ideas about literature derive from English Literature. She is also not cognizant of the fact that she is somehow annihilated because of colonial history. The destructive reality of colonial discourse is more visibly and 
sarcastically exemplified with Asya's university friend Noora, who will later marry Bassam, a Palestinian. Noora is described through books and desert pants. She has eight different publications of the Seven Pillars of Wisdom and has read all of Arabia Desertia. Unknowingly disseminating the discourse of Orientalism with the reproduced copies of Seven Pillars of Wisdom and, as an orientalised Oriental who internalises her orientalisation, or a mock Wispy and a fake T. E. Lawrence, Noora can well be described as a displaced postcolonial female. As explained in the novel, Wispy is

a Western person - they're mostly English although there are some Germans - who is terrifically interested in all things Arab - interested in a deferential sort of way. It is a variant on the Indian theme - the ashram lot rather than the Empire lot. They are the type, you know, who can go native, grow beards, maybe, who take to sandals - they might even learn some Arabic, and a few courtly gestures. It goes with other things too - organic foods, peace (Soueif, 1999, p. 473).

Noora is a telling case in point and, in Saidian terms, is one of the textual children of Empire like Asya. Bassam's displacement disturbs them as they think that the real world is filled with bruised and tortured people as they sit there. Asya is lucky, as she says to herself, she is not a "Palestinian woman living in a camp in south Lebanon [...] nor a Polish Jewess in 1939" (Soueif, 1999, p. 334). However, she thinks that she has not done anything apart from reading poetry. People suffer, and she meditates on words. The sense of displacement is emphasised again in the novel when Sidki al-Tarabulsi arrives to collect Chrissie, her daughter, and Bassam has to hide in another room. He forgets his notes on the table and Sidki picks up one of his copy-books that bears his name. Sidki asks who Bassam is emphasising that he is but a Palestinian. Earlier in the novel, when Asya tells her aunt Tante Muneera about Bassam and Noora, she is baffled the same: “'Palestinian?' Muneera claps her hand to her mouth " (Soueif, 1999, p. 115). Later, Bassam will be thrown out of Egypt during Camp David, and it is interesting that Sidki problematizes the Palestinian background of Bassam whose name turns into a metonymy, but cannot recognise the ambiguity with Chrissie's name as people repeatedly state that it is not an Arabic name. Names remain an issue of disorder in the novel and Chrissie's real name is Carima. Born in England and having lived there till she is five, Carima is called Chrissie; she does not answer to Carima and wants to have her name officially changed. Carima/Chrissie becomes one of the symbols of hybridity with her name while Bassam turns into a metonymic gap for the absence of Palestine through his name. As the emblem of her hybridity, Asya becomes a metonymic gap in the novel through her name as well.

Names become aggregations of opposites in a cultural sense, and they are problematized, as in Romeo and Juliet: "What's in a name [...] were he not Romeo called" (Shakespeare, 2003, 2.2.43-45). As stated before, European literature creates ambivalence for the post-colonial subject, and Romeo and Juliet is alluded to several times in the novel. Asya's master's thesis, as if to attest to her unconsummated marriage, is "Romeo as the Embodiment of the Platonic Ideals of Courtly Love". In another similar instance, Asya listens to the stories of Dada Zeina who introduces to her rural Egypt and suddenly the epistemic control of Empire enters the narrative with Shakespeare: "Juliet was only fourteen" (Soueif, 1999, p. 124). Romeo and Juliet is Asya's standard of growing up as reinforced by quotations from the play. Like Juliet, Asya secretly meets her lover in Beirut and describes this experience through Colette novels. Later in the novel, Asya visits the family tomb and thinks that they are similar to the tombs of the Capulets in the Romeo and Juliet film, and Sheikh Zayid, not Friar Lawrence, stands holding a light above his hand. ${ }^{\text {iii }}$ The triumphant effect of the Empire is such that it reproduces itself and the text returns to (canonical) works of European Literature that hold the control of events.

Friar Lawrence-like Sheikh Zayid is an interesting figure in the novel. He falls in love with a half-Moroccan woman who would not want him because he does not wear European clothes. Sheikh Zayid takes off his Sa'idi clothes and puts on a suit for her sake. The novel shows that for ordinary Egyptians roughly around the 1920s, it slowly becomes the standard to wear European clothes and the fez is no longer worn. Forced sartorial change brings happiness to Sheikh Zayed; however, as a sheikh in European clothes, Zayed carries his zebiba, the 
prayer-spot in the middle of his forehead, as an emblem of his hybridity. He cannot erase it, and his body becomes the site of memory and hybridity.

In this post-colonial novel, the half-Moroccan woman marries Sheikh Zayed provided that he wears European clothes, and Asya quarrels over George Eliot with Saif. This is a pivotal moment in the novel: Saif argues that George Eliot is not worth reading though he has not read her, and Asya bursts out because she thinks he only cares about Sartre, or the Spanish Civil War. Here, Asya describes Saif as Mr Casaubon. She cannot reconcile with the fact that Saif is so sure of himself, like Mr Casaubon, and wants facts. Asya is also angry at her mother who cannot see a point in fighting over George Eliot. Her cultural syncreticity reveals a radical otherness, and she fights with Lateefa because, she thinks, she should care about literature as a professor of English. Although Asya spills out hatred against Sartre and Camus, and fights with Saif over George Eliot, an English novelist, she loves him because he meant freedom for her. This can be compared to Dorothea's awakening moment in Rome in Middlemarch where she learns more about her husband, Mr Casaubon, and is disillusioned afterwards. Like Dorothea, Asya constructs her identity as a response to her husband and her increasing understanding of her marriage puts her in a confining cul-de-sac.

On the other hand, understanding is problematically textual because she thinks that like Dorothea who saw $\mathrm{Mr}$ Casaubon as a brilliant scholar she was walking to freedom with Saif, who read Strindberg and Genet. However, Mr Casaubon cannot complete his masterwork, Key to All Mythologies, and Dorothea is awakened to a new consciousness throughout the novel. After all, Saif ironically thinks that George Eliot is not worth reading and Asya inescapably turns into Dorothea in this post-colonial double of Middlemarch. On the other hand, as a devout reader of novels, Saif wants facts, and he does not believe in telepathy, because of which they also quarrel. In the end, however, his self is a palimpsest of the books he has read, and this is the reason he meant freedom for Asya.Literature and the act of reading turn into an insurmountable obstacle in their relationship, and Asya thinks that Saif wants her to be like the women in the books he has read, especially Mersault's lover in The Stranger. There is an archive of women and Asya thinks they are not real. They do not exist, and they wait to be loved by men, perhaps to love back, or to be beaten and killed by men. Asya becomes an aggregation of all those women who "appear as a face on the wall of Mersault's cell" (Soueif, 1999, p. 345). The interesting thing is that, as an Arab post-colonial subject, Asya is blind to the silenced Arab in the narrative of Camus and is obsessed with intellectual identity and standards of value that are imposed by Empire. As this instance suggests, Asya's hybridity creates an unbridgeable distance with other culturally hybrid people, like Lateefa and Saif, whose ideas are also shaped by European cultural and literary traditions. On the other hand, Asya's hybridity will inordinately be consolidated and more problematized when she goes to England. As Booth (1994) indicates, the Cairo-to-Europe trajectory partly defines the Egyptian intelligentsia's experience in the $20^{\text {th }}$ century (p. 204), and it changes Asya as well.

Asya is repeatedly reminded in the novel that life is not a novel, and, after the quarrel over George Eliot, she paradoxically thinks that she is more comfortable with art than with life. She is concerned with art and life at a time of national insecurity in Egypt, and her hybridity turns into an intergenerational conflict with her mother, whose alterity feeds and reproduces her alterity. When Asya finally breaks up with Saif and talks to her mother, she mimics the words of Cathy in Wuthering Heights: "My love for Saif is like the eternal rocks beneath [...] I am Saif", and Lateefa warns her, "This is not a novel" (Soueif, 1999, p. 568). At another instance, Lateefa warns her again, and this time Asya retorts. Her confusion seems to be a sign of the post-colonial subject's perpetual displacement.

Asya hears the same warning after learning that she is pregnant. She thinks that it is not the right time to have a baby, and Chrissie warns her that life is not a novel, and there is no such thing as a right time for babies. In fact, Asya waits for four years to because her parents do not allow them to get married until after she finishes her studies. Asya thinks that pregnancy is another similar imposition like the delayed marriage. At one point in the novel, she is unhappy because the doctor does not put her on contraception, and she cannot have an IUD 
until after her first delivery. After all, Asya does not want to be childless like the childless instructor Madame Zeinab, but she also does not want to have a baby only four months after marriage. She is in the limbo of romance and sex, sex and desire, desire and marriage, marriage and pregnancy, and later marriage and divorce. She fittingly describes herself as "more or less a virgin" (Soueif, 1999, p. 538). Massad indicates that the motor of the story is Asya's attempt to combine love and desire (Massad and Soueif, 1999, p. 76), and it is important that Saif Madi means "the piercing sword" in Arabic (Malak, 2005, p. 133). Asya's ambiguity shows that her body becomes a site of alterity, and she inhabits the liminal space between words.

The handling of pregnancy in the novel is stunning in another respect. Although In the Eye of the Sun explicitly depicts sensual scenes between Gerald and Asya, it represses sexual encounters between Saif and Asya, perhaps because they do not see each other as desiring bodies (Valassapoulos, 2008, p. 126). Towards the end, only Saif, the untrusted narrator, talks about such incidents. Most important though, sex is not discussed, or is mentioned only in the form of unconsummated sex. Nonetheless, pregnancy is considered at length in the relationship between Asya and Saif. This can be a Flaubertian contribution to the novel because Flaubert never describes sex in Madame Bovary between Emma and her husband, and Emma suddenly appears as a pregnant woman in the next chapter. In an interview, Soueif indicates that the obvious influences to her novel writing are the nineteenth century novelists, especially Tolstoy, George Eliot and Flaubert (Massad and Soueif, 1999, p. 88). Likewise, one chapter ends with unconsummated sex in the novel, and the next begins with Asya's sudden pregnancy in a Flaubertian sense.

To return to the prior point, Gerald also tells Asya that she knows nothing about life and reminds of her Dickensian characters, especially Miss Havisham. Interestingly to note, Miss Havisham is a childless woman and it is seen that English Literature shapes Asya's relationship with Gerald. At one point in the novel, they quarrel, Asya for the first-time answers back and says that Gerald is behaving like Jimmy Porter. Obviously, Gerald does not know anything about the English playwright John Osborne, and Asya paradoxically embodies linguistic and cultural control against an Englishman. He, however, points to the brutal colonial discourse that divides Asya: "Your ideas all come from books. You don't know a thing about real life" (Soueif, 1999, p. 555). No matter what, Asya pays attention only to his grammar mistakes in a moment of post-colonial unsettlement. In the scene, the Egyptian/Oriental has linguistic control, but, as a post-colonial subject, Asya fails to recognise that Jimmy Porter in John Osborne's Look Back in Anger is an angry young man because the Empire has lost its powerful grip on the Suez Canal, and she confusingly uses him as the post-colonial subject's claim to English Literature.

At another point in the novel, Gerald frantically controls Asya's body and her epistemology and forces her to translate letters from Cairo if in Arabic. One is from Chrissie which Asya mistranslates, and the other is from her father with an unlucky English sentence settling in the middle. Upon hearing that Asya is about to break with Saif and has an affair with Gerald, her father writes to her. Though the letter is in Arabic, he says in English that she is making a mess of her life. Asya tries to find an Arabic equivalent for the sentence and thinks that it is almost impossible to say it in classical Arabic. While she is thinking about English and Arabic, Gerald distracts her and wants to hear the translation. This selfish English opportunist that Massad (1999) describes as "overbearing uncouth English hippie" (Massad and Soueif, p. 76) does not want to know what Asya thinks, but to always speak for himself and for her. As stated before, people question Asya's impartiality, but Gerald wants her to excise herself completely and to survive, as a subaltern female, on the negativity of annihilation. He wants her to be his self-reflection. Quite the contrary, Gerald twice indicates that Asya imposes limits in her imagination earlier in the novel and later dictates, like an academic Orientalist, that he knows Asya better than she knows herself. Clearly, Gerald inherits imperialist knowledge and unknowingly executes it.

Asya's assumption of Gerald when they first meet is very novelistic and textual with references to Heathcliff and Wuthering Heights. Emily Bronte's novel shapes the content of In the Eye of the Sun and, when confesses her betrayal, Saif hits her and later that night, he wants to enter her room echoing Cathy's ghost in the novel. 
Towards the end, Asya cannot recognise whether it is Cathy or Saif's voice that she hears, and she finishes her doctoral project with echoes in her head: "- 'Will you let me in?' - a loved familiar figure in an armchair - 'I did a bad thing today?' - or huddled on a rainy pier" (Soueif, 1999, p. 704). Ambivalence remains as part of her hybridity and the scene suddenly changes to New York. This time, Asya is depicted as holding linguistic power against the sexual imperialist Gerald and says that she is being herself. Asya speaks in his words to say that it is over between them and she leaves him.

Throughout the novel, Asya's relationship with Gerald consolidates her hybridity and strengthens her textual trauma. After committing adultery, Asya identifies with Victorian fictional characters: "You've committed adultery [...] joined Anna and Emma and parted company for ever with Dorothea and Maggie - although Dorothea would have understood - would she?" (Soueif, 1999, p. 540). This complex experience of desire and pain is addressed in another scene with literary characters and Soueif shows that Asya's cultural memory is saturated in European literature as she regrets her betrayal and suffers like Ophelia. In a disturbing suicidal scene, Asya wants to be (or die as) Ophelia, who is but chaste. On the other hand, Saif describes Asya as Desdemona when they first meet in Beirut after a very long separation, and before the adultery, and his descriptions are very textual. For Saif, Asya is innocent, but unseeing, like Desdemona.

Asya is either Ophelia or Desdemona and, as a cultural hybrid, she cannot tolerate ambiguity (and this might be the reason that she likes exams). Likewise, her father says that she is intolerant of ambiguity. At one scene, Asya stops writing her dissertation because she thinks there is no use of it and ruminates on the situation of Egypt and the dilemma between life and art. At the English Department in Egypt, professors discuss Heathcliff, Othello and Majnoun, but they set strict rules for their daughters, or encourage, even push, their sons to be doctors and engineers and to join the ruling party. Asya also sees her life as a book written by Saif or his father, but resists the idea. She will, however, sadly accept this saying "he is the imagination and I am the execution: he is the author and the director of our drama and I am just the cast" (Soueif, 1999, p. 593).

Asya believes that her life is not a book, but, as reflected in the imagery of Heights moors with Gerald, she cannot reconcile with England spatially and sees it as a novelistic setting. Upon first visiting her supervisor at the university, she is unhappy to see that his office is very modern. Obviously, she expects a scene from a $19^{\text {th }}$ century English novel. At another time, she is disappointed at a café on the pier in England, "Can't it be warm and cosy with [...] David Copperfield lying open on the coffee-table in front of the fire" (Soueif, 1999, p. 394). ${ }^{\text {iv }}$ By implication, it can be argued that she imagines an England, like the academic Orientalists that imagined the Orient, and her knowledge of the imperial centre is textual because she thinks that what she sees is not England. The actual encounter with England is thus very disappointing for her, and she decides to live in a Victorian cottage and create an England out of her textual knowledge. In a way, she Anglicises herself through space after starting to live in the cottage because she learns about the smell of the fields and wood fire. Moreover, she thinks that she is living in the cottage like a character of a story book. She slowly gets to know about English geography and realises that there are no hedgerows in Egypt. As another example, she wants to see the Castle in a city that she only read about, and upon going there, learns that it is in reality a prison. This instance shows that her understanding of space will eventually be anchored in place and land, and to attest to this, she sees a newly-found stone idol that is buried in sand in rural Egypt at the end of the novel, and identifies with her (Cariello, 2009, pp. 320-321).

Although the ending is hopeful, Asya has a metropolitan understanding of the nature of literature throughout the novel, and this contradiction stems from her internalisation of the culture of the West as the standard. Similarly, when she is in Paris with Saif, Asya imagines a scene with a Daniella, Saif's Parisian ex-girlfriend. She always thinks of her in period clothes, as from a novel by Colette or Katherine Mansfield. As Saif earlier indicates, Danielle, the sad Parisian, comforts herself with him after her Algerian boyfriend illtreats her and, interestingly, all the ex-girlfriends of Saif are European or khawagaya/expatriates. There is a Didi Hashim who has to leave Cairo after the 1952 Revolution, and when Saif learns about Asya's betrayal, she thinks that he 
creates a modern harem in London with American and Scottish women though she is well aware of harem's imagined representation in the West:

A scene from a modern harem, Asya thinks, except that here women ignore each other; there's none of that mutual grooming and gazing you find in the classical stuff. If this had been a Delacroix, now, you would have had Clara leaning over to Mandy's toenails, while Mandy lay back, eyes dreamy, lips half parted, one hand lazily extended to toy with the red tresses that flowed over Clara's smooth, creamy shoulders - she shouldn't stare, Asya thinks (Soueif, 1999, p. 726).

Asya sees herself as Mandy, but thinks that she does not remember what her true self is like. However, it is not only Asya whose alterity is based on texts, but also Saif. As two cultural hybrids, Asya and Saif, shatter under the struggle for endings and beginnings. On their last encounter, he mockingly wants Asya to describe their marriage as a novel:

[...] honestly, even if this were a novel, what kind of a novel would it be? It would be pretty crappy, wouldn't it, if it had us standing here now agreeing to meet in twenty years' time? You could have a sequel then: The Flame of Friendship: Part Two (Soueif, 1999, p. 734).

On the other hand, all the girlfriends of Gerald are from the developing countries, Trinidad, Vietnam or Egypt. For Asya, the reason is obvious. He can be superior and the big white boss. At the end, however, when Asya cries out in the streets of New York to Gerald, she says that he is "a sexual imperialist" (Soueif, 1999, p. 723). Her post-colonial voice stems from the web of filaments that maintain her connection to Egypt, and she recognises that she cannot reconcile either with England or Egypt, but with her hybridity. The ending shows that she can do this, as Edward Said (2012) says

Soueif does not in the end fall for the East versus West, or Arab versus European, formulas. Instead, she works them out patiently, and then goes with Asya, who is neither fully one thing nor another, at least so far as ideologies of that sort are concerned (p. 410).

The novel closes on the assumptions about the burdens of post-colonial hybridity, and there is another model of hybridity that this remarkable novel contests. The discussions now turn to colonial desire in the novel with Robert J. C. Young.

\section{Colonial Desire in In The Eye Of The Sun}

Colonial desire is a concept developed by Robert Young, by which he argues that colonial discourse is saturated in sexuality. As he shows with Gobineau, colonisation is guaranteed the expense of rape and interracial breeding, which is necessary for civilisation, but threatening because it also destroys civilisation (Ashcroft et al., 2004, pp. 50-52). Young (2005) states that the word adulteration combines sexual transgression and adultery with alterity in its root; "ad" and "alter", "the mixture of self and other" (p. 98). He indicates that the relationship between the coloniser (male) and the colonised (female) is seemingly heterosexual and based on racialised sexual hierarchy, domination, violence and power. For Young, the principle of life and death (the inner poison or plague) is the result of the continual adulteration of blood because of racial mixing. The fear of miscegenation is embedded in the writings of Gobineau though he postulates it as the basis for the civilisation of nations, and of particular concern for this paper is septicaemia because Gobineau claims that adulteration of blood is the reason of the fall of nations and that if any civilisation ever existed, it is because of the Aryan elements within it (Young, 2005, p. 122).

In the Eye of the Sun problematizes desire for the post-colonial subject, and, as Joseph Massad (1999) indicates, desire "in Soueif's work, always exists in a context of politics, history and geography all of which are intermeshed and cannot be disentangled" (Massad and Soueif, p. 74). There are four interesting scenes in the novel that disrupt the power of the coloniser with assumptions about colonial desire. These scenes are interrelated and offer a shared understanding of colonial desire. The first is in an English university when Asya 
is invited to a language class to make a demonstration for some Arabic sounds. In the other scene, Asya betrays Saif and sleeps with Gerald, followed by another scene when Gerald imagines Asya as an odalisque and forces her to a role-play. The last one is the rape scene, and buried inside these scenes is a disturbing address of the adulteration of blood in the context of adultery and post-colonial alterity.

Asya arrives in north England in the Autumn of 1973 as a graduate student of Stylistics, and her first feeling is that she is a shadow, or a silhouette. It is not the England that she knows from the books, and her pigeonhole is empty. As an Arab woman, she checks, in vain, both U and A because she is Asya al-Ulama, and $\mathrm{M}$ because she is also Asya Madi. ${ }^{v}$ Her experiences in England start with a problem about her name and Soueif lists several instances of displacements. She is lost in the student hall and drinks water directly from the tap thinking that English people might despise her, or think that she is barbarian.

One day, a phonetics lecturer invites Asya to class and asks her to pronounce some Arabic sounds. He describes a specific sound and Asya demonstrates it through an Arabic word that she chooses. The first word is haraam that is glossed in the novel as "adjective denoting something which is sinful or taboo. It is also used as an adjuration, e.g. to stop someone harming someone, and as an expression of pity" (Soueif, 1999, p. 788). It should be noted that the word has an Islamic sense, for example, adultery is haraam. The second is khiyana which means treachery and betrayal. Treason is also khiyana. The third is antar, an Arab name, also the name of an important pre-Islamic poet. ${ }^{\mathrm{vi}}$ The fourth is the word Qur 'an, but Asya cannot pronounce it. The lecturer lastly wants her to pronounce her name and she cannot do it as well.

Soueif chooses these Arabic words to demonstrate Asya's dilemma of romance and sex, and sex and marriage, and marriage and divorce ad infinitum. Although she glosses khiyana in a political sense, it is zina (fornication) that describes Asya's betrayal. Moreover, the difference in meaning is lost to the non-Arabic speaking, or nonMuslim reader. On the other hand, Saif sees Asya's act of fornication more as treason because she sleeps with an Englishman. As suggested by Asya's silence on the word Qur'an and her name, she becomes the metonymic gap of the text very much like zin̄ which becomes a gap. The scene with Gerald expands on this, and Asya, without uttering the word, thinks on zina, not khiyana. Here, she can reconcile with herself in terms of religion because, as she thinks, the door to repentance is always open, but she cannot erase the fact from her body that Gerald is an Englishman, which makes her act treason for Saif, not only adultery.

As mentioned before, sex and romance (or the unity of the two) constitute a problem for Asya, and desire is surrounded and blocked by colonial domination, though she cannot recognise it. She experiences sex almost always textually though she is married (because she is more or less a virgin). At one point in the novel, Asya theoretically details her feelings and names them in a flowchart with headings such as romance, sex and married love. As a devout reader of novels, she thinks that if sex is good, romance might follow. However, marriage and sex painfully remind her the miscarriage she has before coming to England, the useless birth control and the plastic penis that the English doctor gives to her. Asya names it as Saif's surrogate and frantically keeps it hidden in a fabric brought from Egypt, which is ironically a wedding gift that Tante Adeela, her in-law, gives to her.

Apparently, Asya cannot experience sex with Saif who is reduced to a lifeless plastic penis, and with Gerald, sex is more colonial domination. At one point in the novel, Gerald sits, his legs crossed under him and Asya immediately feels desire. She then enters into a theoretical debate about desire, and her inner speech is controlled by the moral European gaze, "sitting behind your table surveying him as though you were Collette or Piaf or even Kushuk Hanim" (Soueif, 1999, p. 538). It can be argued that Soueif posits Asya as the Kuchuk Hanem and Gerald as the potent European (Flaubert), and this scene makes her the single central consciousness. With Kuchuk Hanem (Little Madame), Soueif questions colonial domination through oriental female sexuality and the moralising Western gaze, and carefully watching Gerald, Asya asks him to spend the night. This attempt to reverse the gaze, because "postcolonial writing often answers the gaze" (Moore, 2008, p. 14), indeed fails because of the ultimate insolubility of desire for the subaltern female. Likewise, Gerald 
returns the gaze in a later scene by making Asya an odalisque and forcing her to look at herself in the mirror. Asya's initiation into sex in a scene that writes about Kuchuk Hanem is very important, because this deOrientalising insight shows that Asya, the Arab/Muslim female Oriental, has a sexual adventure in the imperial centre with the potent European and deconstructs her orientalisation.

Before exploring that pivotal moment, it is helpful to look at Edward Said's discussion of Flaubert and Kuchuk Hanem in Orientalism. Said's discussions of Europeans and sex in the Orient are mostly in the context of Flaubert's writings where the Europeans can have sexual adventures that are rare at home which also deeply shape their imagination of the Orient (Wallen, 2015, p. 12; Valassapoulos, 2008, pp. 329-341). He says that Flaubert describes Egyptian women and speaks for and represents Kuchuk Hanem, a dancer-cum-prostitute, who never talks and represents herself, her emotions, or her history. Said (2003) also states that this is not a specific instance with Flaubert, for it is more a typically Orientalist pattern of relative strength and hierarchised power between East and West that gives Flaubert the power to represent the Oriental (pp. 186-191). Gerald often says to Asya that he knows her better than she knows herself, and he thinks that he owns her, "You're mine. You'll always be mine" (Soueif, 1999, p. 657). Kuchuk's muteness is subverted in Asya's act of speaking for herself, for it is Asya who invites Gerald, and the novel repeatedly depicts the suppression of talking about desire, which, though legitimised under the marriage bond, is unconsummated, not sublimated and always textualised.

As the aggregation of opposites, desire is liberated in Egypt, the periphery and Flaubert's colonial world, and it is entirely textualised in the novel's scenes that pass in Egypt. The moment when Asya and Chrissie find an eclectic collection of pornography of Sidki al-Tarabulsi, Chrissie's father, proposes a similar interrogation. Asya wants to be left alone with the magazines because she cannot look at them when Chrissie is looking at her and says "the features are always abstracted, decorous, like the faces of Pharaonic statues [...] the men mostly have no faces" (Soueif, 1999, p. 80). Desire, though liberated because it is freely discussed especially with lower-class women, is under surveillance here and problematized (with lifeless statues). This early scene underlines the boundaries of desire with race and, as an Oriental, or Arab, Asya contrasts the collection with The Perfumed Garden of Sheikh Nefzawi that she read as a child. In many scenes in the novel, there are references to The Perfumed Garden, the most interesting of which is about the Arabic word for vulva. Lady Hamdonna, a character in The Perfumed Garden, says: "On every vulva there is written the name of the man who is destined to enter it" (Soueif, 1999, p. 580).

However, Asya thinks only about sexualised translation and recognises that the word vulva never appears in Arabic except for the translations of Arabic erotica. Soueif's central concern here hinges on the fact that colonial desire and translation intersect, as seen in Burton's translation of the Arabian Nights, and it should also be reminded that the Arabic word 'awra, which means a private body part that should not be revealed (Malak, 2005, p. 125), can also be translated as female genitalia (Moore, 2008, p. 13). As with the word vulva, Asya thinks about 'awra in relation to Literature because one of her female students in Cairo refuse to speak (English) in the class because "the voice of a woman is "awra" (Soueif, 1999, p. 754). This student remains silent like Flaubert's Kuchuk Hanem, and Asya feels as a porn-star.

As seen in the non-existent vulva and 'awra, the Flaubertian moment with Gerald reiterates language as an index of desire and fear for the post-colonial hybrid. Asya continuously ridicules and jokes about her unconsummated marriage, and her initiation into sex only in the form of adultery and rape points to Robert Young's theory of colonial desire. While thinking about desire in the marriage context, Asya fantasises about men from different races and ethnicities, a mix that replicates Sidki's pornography collection. As a rethinking this post-colonial text produces, Asya, Gerald's Kuchuk, turns into Flaubert in her inner monologue; the potent European, and Soueif presents a parodic address of desire and race with Hercules, Ganymedes, African warriors, California tycoons and Leons. However, the narrative abruptly returns to an excerpt from her doctoral 
thesis which points to the insolubility of desire for Asya as the female subaltern who experiences sex negatively either through adultery or rape.

It should be stated also that, in the context of English Literature, betrayal/adultery is a peripheral moment in Victorian fiction. As Said (1994) says, the heroine "is surprised, not to say shocked, by the sudden revelation of a lover's betrayal [in Middlemarch]: Dorothea sees Will Ladislaw apparently flirting with Rosamond Vincy [...] Then the women awake to a new awareness of themselves and the world" (p. 173). Betrayal becomes problematic in In the Eye of the Sun because although Asya is the Kuchuk Hanem, she subversively becomes Flaubert, and although she identifies with Dorothea throughout the novel, she turns into Will Ladislaw. More than that, Said (2012) says that "in many ways Asya is her own Casaubon" (p. 409). It is seen that only through negativity can desire be transformed from the textual and the imagined into the real in Asya's life. For that reason, sex is literally painful for her as she says the physical "pain doesn't go as the books said it would" (Soueif, 1999, p. 540).

Desire is the motor of the narrative and, as an adulteress, or as confined to the untranslated Arabic word muhasanah in the text, Asya consolidates her hybridity through desire. Soueif signals an important debate and explores the perpetuating dominance of religion for Asya about desire. She is not only an adulteress but also a muhasanah that is glossed as "from hasanah, to fortify. A woman who is fortified (through having her desires satisfied in marrage) from the sin of adultery" (Soueif, 1999, p. 789). After the height of the act, Asya thinks about being a muhasanah, and her cultural syncretism is implicit because she thinks that Dorothea, in Middlemarch, also an adulteress, is Victorian. The emphasis is on constrained Victorian sexuality, and Asya states that she is a modern Arab woman, but also Muslim, which brings to her mind the stoning practice for the punishment of fornication in Islam. The imagery with stones is remarkable because Soueif problematizes desire with numb bodies, death, and sculptures in the novel (Cariello, 2009, p. 317-318). In this scene, Asya's religious background is unmasked when desire is presented as a problem with diverse ramifications for the female subaltern. Asya thinks that she is not a muhasanah because there has to be four witnesses who see the act. Linda F. Maloul (2017) emphasises that "Asya's family's Islam seems to be an urban and secular Islam" (p. 77), but she thinks about adultery as zinā (thereby stoning to death), which turns into treason/khiyana perhaps because she is female. Desire here becomes, together with language, a threshold and a dangerous opening of the self to the other (Moore, 2008, p. 157), and therefore treason.

Desire is also a problem because it is an act of colonial domination for Gerald. He wants to make a sensual role-play with Asya, his beautiful Eastern butterfly as he calls her, and in that scene the reader recognises the “"exoticising effects' of colonial stereotypes in the western male's gaze" (D'Alesssandro, 2011, p. 92). Strange is the fact that, as Young emphasises (2005), the desiring and civilising white male is sexually attracted to the yellow and black races who repulse (this is the axis of attraction and repulsion) and the execution of civilisation is based on colonial desire, thereby on hierarchical power and violence (pp. 66, 97). ${ }^{\text {vii }}$ Gerald takes off Asya's clothes and wants her to look at herself in the mirror: he wants her to see herself. Asya wants to switch off the lights and Gerald says that he always wants to see Asya naked and perfumed, her hair falling over the shoulders and wearing her jewels only. The irony is that it is not Gerald, but Saif, who buys the jewels, and Asya asks to see if he wants an odalisque. Gerald does not know the meaning of the word although it is an odalisque that he wants. Asya's thoughts here slip into great seascapes and empty scenes, into frames from Death in Venice, and it is interesting to note that the plague in Death in Venice is of Asiatic in origin. Edward Said says (2003), "In Mann's great fable of the alliance between creativity and disease -Death in Venice- the plague that infects Europe is Asiatic in origin: the combination of dread and promise, of degeneration and desire" (pp. 227-228). Similarly, in Guy Boothby's Pharos the Egyptian written in 1899, a virulent plague kills millions of people in Europe. This oriental disease is spread from Port Said where the Suez Canal facilitates not only the transportation of imperial goods to Britain, but also an epidemic disease (Bulfin, 2011, p. 425). The emphasis on plague is very important because, as with Gobineau, the underlying point here is the fear of miscegenation and inescapable death because of colonial desire. 
It is seen that degeneration and desire unite in the relationship of Asya and Gerald, and she can experience sex through adultery resonant with colonial desire. The contradiction of her position is stressed with language and the only word that Gerald speaks out at the orgasmic moment is her name. Asya becomes her name and the text annihilates her. As explored in the scene where Asya cannot pronounce her name, she again becomes a metonymic gap, a muhasanah, because although Gerald roars out "Asya", he will always call her as babe, or baby, or man, and this ensures the complete annihilation of Asya as a female subaltern through what she calls sexual imperialism (Cariello, 2009, p. 319). For Asya, desire is an index of fears, violations, numbness, death, adultery and rape, and no matter what, it is textual.

Massad (1999) emphasises that Soueif "explores desire not as a Western binary as hetero- and homosexual desire, but rather as a fluid set of possibilities existing on a continuum" (Massad and Soueif, p. 77). Young's discussion on homo-eroticism in racial mixing also explains the uncertain nature of desire for the female subaltern in the novel. Young highlights the exclusive importance of homo-eroticism in the theses of racial mixing and indicates that if all black or yellow races are female or feminised, it comes to mean that the white male is attracted to both sexes. Young (2005) argues that civilisation begins to merge with interracial homoeroticism because sexual difference is translated into the sexual division of races as Gobineau speaks about a paradoxical preference for the feminised black races p. 104). This is particularly apparent in the scene when Saif learns Asya's betrayal. He yells at Asya to invite Gerald so that he can have sex with him, too. On the other hand, unlike in the Victorian novelistic tradition, it is Saif who is awakened after betrayal and he sees Asya's betrayal as khiyana/treason: "An Englishman. You fucked an Englishman". Asya definitely sees the point and asks, "Would it have been better [...] if he'd been Egyptian? Or Iraqi? Or Palestinian?" (Soueif, 1999, p. 630). Here, desire oscillates between zinā and khiyana, and Saif leaves Asya with ambiguity because he thinks that she sleeps with an Englishman that she does not know, or cannot possibly know. There is cultural separatism and hierarchical essentialism in Saif's agony because Gerald can know the Oriental, and he ensures that he does, but Asya can never know an Englishman. Besides, this Englishman can desire him too, which also makes Asya's plastic penis Saif's substitute. Angrily, Saif rapes Asya at the end, and this is the only moment they experience sex as a married couple.

\section{Conclusion}

Lastly to note is that Asya's almost hysterical fear for the lifeless plastic penis can be interpreted in the context of oriental sexuality with Flaubert. Orhan Pamuk observes in his Istanbul: Memories and the City an important deliberate omission in Said's handling of Flaubert, which for him points to the fact that Said reads texts selectively. Pamuk indicates that Said ignores evidence that does not point to Orientalism as a discursive tool, and he narrates a story of Flaubert's failed and embarrassing sexual encounter with an Istanbulite seventeenyear-old girl. Flaubert visits the filthy brothels of the city with a dragoman, where the women are ugly, and he wants to leave at once. The madam offers him her own daughter and the girl wants to inspect his penis for syphilis, but as he still has induration and fearing that she might see this, Flaubert gets out of the bed and says that she insults him. This is a disempowering moment for the European male because Flaubert cannot expose his body to the oriental female gaze like the syphilitic patients in Cairo who pull down their trousers and "display their chancres for the benefit of visiting Western physicians" (Pamuk, 2006, pp. 367-368). Pamuk emphasises that Flaubert studies them carefully and takes notes about them in an attitude of seeing another filthy oriental custom and oddity and, for Pamuk, such a scene of emasculation does not suit within the narrative of Orientalist mastery and domination that Said is talking about. Therefore, he omits it (Teltscher, 2009, p. 138).

In a similar manner, Asya is very nervous about the materiality of the plastic penis and fears that people will accidentally see it. As a parallel to this, there is a scene in rural Egypt where local women giggle over an erect penis that Asya uses for the contraception campaign she works for. After all her problems with sex and marriage, marriage and desire, and married sex and romance, and so on, it is ridiculously paradoxical that she 
works for a contraception campaign as a professor of English. A young woman there asks Asya about her delayed period, and she says that she is not a medical doctor and the woman shockingly asks about her title. Asya briefly explains a Ph.D. in Literature, but the woman cannot see a point in studying poetry and stories. Unsurprisingly, Asya describes these women in novelistic terms saying "they are worthy of romance" (Soueif, 1999, p. 758). This striking moment summarises her post-colonial dilemma and consolidates her hybridity. This interesting irony ends the novel and Soueif, like in her second novel, The Map of Love, fictionalises postcolonial debates in In the Eye of the Sun. She draws the attention of the reader to the imperial encounter which shows that the coloniser bears the traces of the post-colonial Other who also carries traces as scars. For Asya's case, these scars arise from desire in particular and make hybridity the theme of the novel.

\section{References}

Ahmad, A. (2000). In theory, classes, nations, literatures. London: Verso.

Albakry, M., \& Hancock P. H. (2008). Code switching in Ahdaf Soueif's The Map of Love. Language and Literature. 17(3), $221-234$. doi: $10.1177 / 0963937008092502$.

Ashcroft, B. (2001). Post-colonial transformation. Retrieved from https://www.routledge.com/Post-Colonial-Transformation-1st Edition/Ashcroft/p/book/9780203129814.

Ashcroft, B., Griffits, G., \& Tiffin, H. (2004). The empire writes back, theory and practice in post-colonial literatures. Retrieved from https://www.routledge.com/The-Empire-Writes-Back-Theory-and-Practice-in-Post-Colonial-Literatures/Ashcroft-GriffithsTiffin/p/book/9780415280204.

Ayad, N. (2016). The politics of foreignizing and domesticating English in Ahdaf Soueif's In the Eye of the Sun. Translation Review, 95(1), 55-66. doi: 10.1080/07374836.2016.1182831.

Basnett, S., \& Trivadi, H. (2002). Introduction. In S. Bassnett \& H. Trivedi (Eds.), Post-colonial translation, theory and practice (pp. 1-18). Retrieved from https://www.crcpress.com/Postcolonial-Translation-Theory-and-Practice/Bassnett-EditorTrivedi/p/book/9780415147453

Bhabha, H. (1984). Of mimicry and man: The ambivalence of colonial discourse. October, 28(A Special Issue on Psychoanalysis), 125-133. Retrieved from http://www.jstor.org/stable/778467.

Bhabha, H. (2003). The location of culture. London and New York: Routledge.

Booth, M. (1994). In the Eye of the Sun by Ahdaf Soueif. World Literature Today, 68(1). Retrieved from http://ww.jstor.org/stable/40150073.

Boccardi, M. (2004). History as genealogy: A.S. Byatt, Tracy Chevalier, Ahdaf Soueif. Women: A Cultural Review, 15(2), $192-203$. doi: 10.1080/0957404042000234042.

Boccardi, M. (2009). The contemporary British historical novel, representation, nation and empire. Great Britain: Palgrave Macmillan.

Bulfin, A. (2011). The fiction of Gothic Egypt and the British Imperial paranoia: The curse of the Suez Canal. English Literature in Transition 1880-1920, 54(4), 411-443. Retrieved from http://muse.jhu.edu/article/445326.

Cariello, M. (2009). Bodies across: Ahdaf Soueif, Fadia Faqir, Diana Abu Jaber. In L. A. Maleh (Ed.), Arab voices in diaspora, critical perspectives on anglophone Arab literature (pp. 313-338). Amsterdam: Rodopi.

Crabbs, J. Jr. (1975). Politics, history, and culture in Nasser's Egypt. International Journal of Middle East Studies, 6(4), 386-420. Retrieved from http://www.jstor.org/stable/162751.

D'Alessandro, S. (2011). Politics of representation in Ahdaf Soueif's The Map of Love. Bern: CHE, Peter Lang.

Eagleton, T. (2005). The English novel: An introduction. USA: Blackwell Publishing.

Floyd, J. (2004). Coming out of the kitchen: texts, contexts and debates. Cultural Geographies, 11(61). doi: 10.1191/1474474003eu293oa.

Heilmann, A., \& Llewellyn, M. (2004). Historical fictions: Woman (re)reading and (re)writing history. Women: A Cultural Review, 15(2), 137-152. doi: 10.1080/0957404042000234006.

Mahjoub, J. (2010). A correspondence with Ahdaf Soueif. Wasafiri, 24(3). doi: 10.108002690050903019822.

Malak, A. (2005). Muslim narratives and the discourse of English. Albany: State University of New York Press. 
Maleh, L. A. (2009). Anglophone Arab literature: An overview, In L. A. Maleh (Ed.), Arab voices in diaspora, critical perspectives on anglophone Arab literature (pp. 1-63). Amsterdam: Rodopi.

Maloul, L. F. (2017). Political Islam, Islam as faith and modernity in 1970s Egypt: A socio-political reading of Soueif's In the Eye of the Sun. Contemporary Levant, 2(2), 77-88. doi: 10.1080/20581831.2017.1365448.

Massad, J., \& Soueif A. (1999). The politics of desire in the writings of Ahdaf Soueif. Journal of Palestine Studies, 28(4), 74-90. Retrieved from http://www.jstor.org/stable/2538394.

Moore, L. (2008). Arab, Muslim, woman, voice and vision in postcolonial literature and film. Oxford: Routledge.

Mullaney, J. (2010). Postcolonial literatures in context. London: Continuum.

Nash, G. P. (2009). From Harem to Harvard: Cross-cultural memoir in Leila Ahmed's A Border Passage. In L. A. Maleh (Ed.), Arab voices in diaspora, critical perspectives on anglophone Arab literature (pp. 351-370). Amsterdam: Rodopi.

Nash, G. (2008). Re-siting religion and creating feminised space in the fiction of Ahdaf Soueif and Leila Aboulela. Wasafiri, 17(35), 28-31. doi: 10.1080/02690050208589768.

Pamuk, O. (2006). Istanbul: Memories and the city. (M. Freely, Trans.). Retrieved from: https://www.barnesandnoble.com/w/istanbulorhan-pamuk/1100992512?type=eBook\#.

Parry, B. (2004). Postcolonial studies: A materialist critique. London: Routledge.

Said, E. W. (1994). Culture and imperialism. London: Vintage Books.

Said, E. W. (2003). Orientalism. New York: Vintage Books.

Said, E. W. (2012). Reflections on exile and other literary and cultural essays. London: Granta.

Shakespeare, W. (2003) Romeo and Juliet. G. B. Evans (Ed.). Cambridge: Cambridge University Press.

Soueif, A. (1995). Sandpiper. London: Bloomsbury.

Soueif, A. (1999). In the Eye of the Sun. London: Bloomsbury.

Teltscher, K. (2009). Reading orientalism in Istanbul, Edward Said and Orhan Pamuk. In R. Ghosh (Ed.), Edward Said and the literary, social and political world (pp. 137-150). Retrieved from https://www.crcpress.com/Edward-Said-and-the-Literary-Social-andPolitical-World/Ghosh/p/book/9780415647441.

Valassopoulos, A. (2008). Contemporary Arab women writers, cultural expression in context. Retrieved from https://www.routledge.com/Contemporary-Arab-Women-Writers-Cultural-Expression-in-

Context/Valassopoulos/p/book/9781138010345.

Wallen, J. (2015). Sexual anthropology: Burton and Said's gendered axis. The Victorian, 3(2), 1-31. Retrieved from http://journals.sfu.ca/vict/index.php/vict/article/view/171.

Young, R. J. C. (2005). Colonial desire, hybridity in theory, culture and race. Retrieved from https://www.routledge.com/ColonialDesire-Hybridity-in-Theory-Culture-and-Race/Young/p/book/9780415053747.

\section{Notes:}

${ }^{i}$ Arabic words are spelled out as they are found in Western publications. Existing spellings of the quoted materials are preserved.

ii Built for the opening of the Suez Canal at a huge expense, the Opera House in Cairo consolidates the power of Empire in Egypt: Verdi composes Aida for the triumph. On Black Saturday, during Cairo Fire on the 26 ${ }^{\text {th }}$ January 1952, nearly 750 buildings owned and associated by Europeans such as nightclubs, theatres, cafés, hotels and operas are burnt in Downtown Cairo.

iii Ailise Bulfin (2011) indicates that the Egyptian tomb appears as an unsettling place in the Egyptian-themed gothic fiction in Victorian England as the English trespass into an ancient Egyptian tomb, removes a mummy or brings the artefacts into England and is cursed by a supernatural invader that comes to the metropolitan centre for revenge (pp. 413414). 
iv Janet Floyd (2004) argues that Anglo-American post-colonial analysis pictures the kitchen as the arena for the domestication of for the colonised and the exploited female other (p. 62).

' Arab women do not take their husbands' surname.

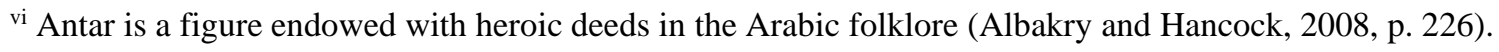

vii Georges Cuvier (1769-1832) puts forward a theory of race with yellow, black and the white as the three major races (Ashcroft et al., 2004, pp. 27, 220). Mullaney (2010) states that colonial constructions of race are pigmentocratic in nature (p. 52). 